\title{
Internal ministerial advisory bodies: An attempt to transform governing in the Slovak Republic
}

\begin{abstract}
In the Slovak Republic, a number of internal ministerial advisory bodies, intended to provide high-quality analyses and evidence based policy making for national policy, have been established over the last two years. We have studied how the rational technocratic model of scientific policy advice as a specific mode of governing, acted out through these new institutional sites of expertise, survives in a highly politicised environment of the Slovak public administration. Central to our study was the reconstruction of an intersubjective account central to the work of organising on which the analytical centres and their staff, as well as their patrons, participate. Complementary to this, we focused on intersubjectively shared elements of the analysts' community and subculture within the dominant CEE public administration culture. The vision of governing with expertise shared by analytical centres rests on the principles of transparency, orientation on professional merit (primarily econometric, analytical skills), voluntarism, conflict avoidance, political opportunism and institutional autonomy. Analytical centres identify themselves as a distinct professional group - in fact, they form a distinct organisational subculture around traits such as demographic characteristics (predominantly young males with economic or mathematicallIT background), symbols, hierarchies, working culture, humour, as well as artefacts. Analysts see their mission in the provision of impartial, objective analytical evidence for informed decision making, yet they negotiate the boundary between politics and expertise on a daily basis, and, as we found, in numerous aspects of analysts' work politics cannot be entirely bracketed.
\end{abstract}

KEYWORDS: scientific policy advice; advisory bodies; evidence-based policy making; accounts of practice; civil service; Central and Eastern Europe

RECEIVED 26 February 2018; ACCEPTED 4 June 2018.

\section{INTRODUCTION: CEE TRANSITION AND ANALYTICAL CAPACITY IN SCIENTIFIC POLICY ADVICE}

In the policy advice literature, the origins of the debate about scientific policy advice is linked to traditional concept of 'speaking truth to power' by Wildavsky, whose prototype of a policy analyst was embodied by the civil servant. Numerous studies have focused on the capacity and ability to produce internally sound scientific analyses to inform policy making in single case studies, particularly in English-speaking countries (Canada, Australia, UK, US and New Zealand in particular). CEE countries remained in the fog of the first communist regimes and later the EU accession process, within which, not much discretion for civil service driven scientific advice was considered to be possible. At the same time, as noted by Colebatch (2017) in the previous issue, researchers from this region only sporadically assisted to lift this fog by indigenous research of the actual practice. This paper responds to his call upon researchers and aims to uncover the accounts of practice that help conduct the work of governing in recently established ministerial advisory units in Slovakia, focusing in particular on traversing the boundary between politics and impartial expertise.

Scientific policy advice is understood in the frame of instrumental rationality where knowledge is objective, can be quantified and verified by empirical methods (Majone, 1989; Jasanoff 1990), and can be used to improve decision making. 'Informed decisions' require 'unbiased' evidence, associated with quantitative techniques in particular. Since Wildavsky's famous phrase decisive transformations have occurred in the governments and decision making of the Western democracies, such as shifts from traditional

1 Michal Sedlačko: Competence Centre for Administrative Sciences, University of Applied Science FH Campus Wien, Vienna, AT. Email: michal.sedlacko@fh-campuswien.ac.at

2 Katarína Staroňová: Institute of Public Policy, Comenius University in Bratislava, Bratislava, SK 
state-centred, hierarchical models towards more horizontal decentralized governance patterns with multiple actors providing the advice (Halligan 1995, Craft and Wilder 2017). Accordingly, recent research into policy advice shows a shift towards externalisation and hybridisation of policy advice, and thus, away from a reliance on internal civil servants (Halligan, 1995; Veselý, 2013; van den Berg, 2017; OECD, 2017; Veit et al., 2017). Studies on institutionalised sources of policy advice address a range of actors from ministerial cabinets and their political advisors, individual policy advisors as well as policy advice units in line ministries or centralised in the Cabinet, political think tanks of the political parties or think tanks, research organisations and academia, to trade unions, interest groups and private consultancy services. Nevertheless, some governments have responded to this increased complexity of providers with the establishment of internal distinct advisory units, advisory councils and/or special senior scientific advisors in order to support evidence based policy making (HM Government, 1999; Bressers et al., 2018; Crowley and Head, 2017). The functions these have been endowed with range from policy brokerage (What Works Network of analytical units in the UK) ${ }^{3}$ to primary research (such as the Netherlands Planbureaus providing impartial analysis rather than recommendations and advice, Van de Haar, 2015). Many of the governments have embedded analysts in their respective policy directorates conducting central coordination, oversight and/or support, such as the function of 'Chief Analyst' and 'Chief Scientific Advisor' in the UK.

Only scarce evidence on policy advice in the countries of Central and Eastern Europe exists. The few case studies that exist are mostly focusing either on the role of political advisors (Keris, 2008; Majcherkiewicz, 2008; Cobarzan, 2008) or dangers of contracting out the policy advice (Raudla, 2012; Sedláček \& Veselý, 2016). In either case, the studies show limited internal capacities inside of the governments, particularly for producing scientific policy advice. This is also confirmed by the studies on regulatory impact assessment that show absence of evidence and low quality of analyses conducted internally in the CEE countries (Staroňová, 2014). Since the early 1990s and continuing after the accession of these countries to the EU, the strengthening of advisory capacity (as well as administrative capacity in general) was typically conducted through projects involving Western consultants and in the frame of institutional transition from the Communist (pre-1989) public administration to a 'standard', 'Western', 'modern' or 'democratic' public administration and policy or 'good governance'. The account driving this reform presented this as an opportunity to overcome excessive politicisation and strengthen professionalism. ${ }^{4}$ According to research focusing on the capacities and performance of formal institutions - and with a view of policy as an authoritative choice (Colebatch, 2010, p. 32) conducted by an institutional formation, most countries failed to achieve this objective (Meyer-Sahling, 2001; Verheijen \& Kotchegura, 1999). Nevertheless, very little research - and mostly anecdotal evidence only - exists on the impact of this reform account on the actual practice of governing. Research focusing on reforms through changes in formal institutions has mostly omitted the 'domestication' and local translation of an otherwise internationally produced and circulated hegemonic account of institutional reform, as well as its purely symbolic adoption, that is, the setting up of an internationally acceptable institutional façade with few real changes in practice or continuing strong politicisation. Such rare research includes notions such as 'empty shells' (Dimitrova, 2010), 'dead letters' (Falkner \& Treib, 2008), or 'the best laid plans' (Grzymala-Busse, 2010) - and there is now also emerging research on 'functional politicisation' (cf. Peters, 2001) and informal institutions. The latter shows how maintaining and developing high institutional competence and professionalism might involve specific types of (bottom-up) politicisation supported by informal institutions and practices that bypass (top-down) official, formal institutions and regulation (Staronova \& Gajduschek, 2017; Sundell, 2014).

In the Slovak Republic, a number of internal ministerial advisory bodies, intended to provide high-quality analyses and evidence based policy making for national policy, have been established and/or restructured over the last two years. We studied how the rational technocratic model of scientific policy advice as a specific 'mode of governing', acted out through these new analytical centres, survives in a highly politicised environment of the Slovak public administration. We focus on the account of governing, and its underlying notions of reform of public administration and policy, that helps organise this mode of governing - and which is in stark contrast to the top-down accounts of institutional reform. By doing this, we would also like to engage Colebatch (2017) on

3 The network was launched in 2013 in order to help identify which social policy interventions are the most effective (Bristow et al., 2015).

4 Such a reform account was supported by a general 'counter-Communist' discursive frame, applied locally in a number of areas of societal transformation after 1989 in most of the CEE countries (through which anything labeled as Communist was painted in sometimes excessively negative light), as well as accounts of (good) governance or New Public Management (NPM) that, often, in lieu of solid analysis, misrepresent contemporary (i.e., 'old') practice to the point of caricature. Note that the research indicates that by the late 1980 s, the typical 'spoil system' (meaning political patronage) of the Communist regime showed elements of merit-based system since the lack of democratic elections ensured relative stability, which in turn allowed for accumulation of knowledge and skills obtained from work experience and trainings (Gajduschek, 2007). Political loyalty also gradually lost its importance after the consolidation of power and gave way to professional, that is, stable and relatively capable, civil servants (ibid.). 
the topic of transition of Central and Eastern European (CEE) countries and post-communist narratives of policy and governance as well as help sensitise CEE scholars to adopt a more practice-oriented and processual perspective of the work of governing ('first-order accounts' of Noordegraaf et al., 2010).

In the next section, we provide a brief description of the structure and history of internal ministerial advisory bodies, the object of our research. The third section discusses our method and the theoretical underpinnings that guide our interpretative investigation of accounts. The fourth section presents our findings, structured into four areas: (i) the vision of governing in the account that serves as a central axis of the 'mode of governing' manifested by the analytical centres, (ii) the transposition on the subjectivities of an analyst, focusing on motivation and expertise, (iii) analysts as a distinct professional group and organisational subculture, and (iv) boundary work in the terrain where impartial expertise and politics meet. Lastly, in the conclusion, we attempt to draw some widerreaching implications of our findings.

\section{MINISTERIAL INTERNAL ADVISORY BODIES IN SLOVAKIA}

To refer to the internal institutionalised entities established in Slovakia over the recent years by line ministries within their hierarchies but close to prime political decision makers (line ministers or state secretaries), we use the emic term 'analytical centres' (ACs) throughout the paper. ACs are thus distinct from committees, working groups, oversight or political advisory bodies comprised of ad hoc officials, experts, and/or academia. ${ }^{5}$ Their mission lies in the provision of scientific policy advice requiring substantive and technical-analytical skill, and in this way, in the contribution to evidence-based policy making and informed political debate. Typically, such advice includes problem structuring and impact analysis of several intervention options (usually utilising some variant of cost-benefit or cost-efficiency analysis), or recommendations on optimisation of existing policy.

Since 2016, eleven analytical centres have come into being or were restructured (see Table 1). Out of these, six have been newly established and five emerged through restructuring of the ministries' existing ACs. ${ }^{6}$ This proliferation has been instigated by the Institute of Financial Policy (IFP) at the Ministry of Finance, which has been considered a flagship of impartial policy advice in the country for more than a decade.

This current wave does not constitute a first attempt at such an undertaking. The first ACs were established in 1992 with the creation of the Slovak Republic as a replication of Czechoslovak federal (and presumably previous Communist era) ministries located in Prague (Czech Republic), for example, the AC at the Federal Ministry of Foreign Affairs. The second wave took place around the time of the EU accession and the largest reforms were conducted under PM Dzurinda's second government and his influential Minister of Finance Ivan Mikloš, known for having an expertise-driven reform vision (roughly 2002-2004). This wave included a reorganisation of existing ACs and establishment of new ones, including the IFP that was the only AC to survive all the subsequent government changes. Six ACs were established in the next, third wave that took place in 2010-2012 during the government of PM Radičová, achieving varying levels of influence on decision making. ${ }^{7}$ The waves were always initiated after a change of government. Nevertheless, the current fourth wave is the most comprehensive attempt so far, involving all the ministries, ${ }^{8}$ as well as the Government Office.

This fourth wave occurs against the background of several wider developments. First, there has been an increase in the calls for evidence-based national-level policy making. Through a series of public meetings, public discussions and articles in the press, the IFP

5 From the institutional perspective, OECD (2017) suggests to look at distinct institutional features of the internal advisory bodies such as the life span (permanent vs. ad hoc), organizational structure (council vs. institute) and position (legal and managerial autonomy) to distinguish the reason for introducing and degree of independence from government.

6 None of the ACs has been established through a constitutional decree - and are therefore potentially easy to dismantle under a less supportive government.

7 Only few of these could be considered successful. It would seem that the main reason for lack of influence was large distance from political patrons or their symbolic (Weiss, 1979) or legitimizing (Cash et al., 2003; Bosswell, 2009), rather than technical-instrumental, role.

8 Out of 13 ministries in total - all the ministries were originally covered by the EU SF project. Also, each ministry was offered human capacity assistance from the IFP, accompanied by finances from the EU SF to cover the institutionalisation costs. Nevertheless, the political leaders of the Ministry of Defence Transport refused. In fact, the right populist leader of the Slovak National Party from the MoD publicly claimed on TV that 'there is no such thing as value for money, defence cannot be measured, defence means there is no war' $\left(10^{\text {th }}\right.$ May, TA3). 
Tab. 1: Overview of analytical centres in Slovakia (as of January 2018).

\begin{tabular}{|c|c|c|c|c|c|}
\hline Analytical Centre & Parent institution ${ }^{1}$ & $\begin{array}{l}\text { Time of } \\
\text { existence }\end{array}$ & Predecessor ${ }^{4}$ & External financing $^{5}$ & Staff \\
\hline $\begin{array}{l}\text { Unit of Analysis and } \\
\text { Planning (UAP) }\end{array}$ & $\begin{array}{l}\text { Foreign Affairs } \\
\text { (MoFA) }\end{array}$ & $1992-$ present $^{2}$ & Federal UAP & no & $\begin{array}{l}\text { Less than } 20 \\
\text { (dynamic) }\end{array}$ \\
\hline $\begin{array}{l}\text { Institute of Financial } \\
\text { Policy (IFP) }\end{array}$ & $\begin{array}{l}\text { Finance } \\
\text { (MoF) }\end{array}$ & 2003 - present & yes & World Bank project & $\begin{array}{l}26+5 \\
\text { contractual }\end{array}$ \\
\hline $\begin{array}{l}\text { Institute of Security and } \\
\text { Defence Studies }\end{array}$ & $\begin{array}{l}\text { Defence } \\
\text { (MoD) }\end{array}$ & $2003-2012^{3}$ & $\begin{array}{l}\text { yes } \\
\text { (est. 1993) }\end{array}$ & $\begin{array}{l}\text { No } \\
\text { (2016 EU SF proposal } \\
\text { rejected by } \\
\text { the political leader) }\end{array}$ & $\mathrm{n} / \mathrm{a}$ \\
\hline Institute of Strategy & $\begin{array}{l}\text { Transport and } \\
\text { Construction } \\
(\mathrm{MoT})\end{array}$ & $2010-2012^{3}$ & no & $\begin{array}{l}\text { No } \\
\text { (2016 EU SF proposal } \\
\text { rejected by } \\
\text { the political leader) }\end{array}$ & $8+5$ \\
\hline $\begin{array}{l}\text { Institute of Educational } \\
\text { Policy (IVP) }\end{array}$ & $\begin{array}{l}\text { Education, Science, } \\
\text { Research and Sports } \\
\text { (MoEdu) }\end{array}$ & $2013-J a n .2018^{3}$ & no & $\begin{array}{l}\text { EU SF } \\
\text { ('Effective PA') }\end{array}$ & $6+1$ \\
\hline $\begin{array}{l}\text { Value for Money Division } \\
\text { (VfMD) }\end{array}$ & $\begin{array}{l}\text { Finance } \\
\text { (MoF) }\end{array}$ & March 2016 & no & $\begin{array}{l}\text { EU SF } \\
\text { ('Effective PA') }\end{array}$ & 14 \\
\hline $\begin{array}{l}\text { Centre for Economic } \\
\text { Tasks }\end{array}$ & $\begin{array}{l}\text { Economy } \\
\text { (MoEcon) }\end{array}$ & Apr. 2016 & $\begin{array}{l}\text { Institute of Eco- } \\
\text { nomic Analyses } \\
\text { (est. 2011) }\end{array}$ & $\begin{array}{l}\text { EU SF } \\
\text { ('Effective PA') }\end{array}$ & 8 \\
\hline Analytical Centre & $\begin{array}{l}\text { Justice } \\
\text { (MoJ) }\end{array}$ & May 2016 & no & $\begin{array}{l}\text { EU SF } \\
\text { ('Effective Judicial } \\
\text { System and Law } \\
\text { Enforcement') }\end{array}$ & $11+1$ \\
\hline Analytical Centre & $\begin{array}{l}\text { Government Office } \\
(\mathrm{GO})\end{array}$ & May 2016 & no & EUSF & 6.5 \\
\hline $\begin{array}{l}\text { Institute of } \\
\text { Environmental Policy } \\
\text { (IEP) }\end{array}$ & $\begin{array}{l}\text { Environment } \\
\text { (MoEnv) }\end{array}$ & July 2016 & $\begin{array}{l}\text { Unit of Economic } \\
\text { Tools and Analyses } \\
\text { (est. 2012) }\end{array}$ & $\begin{array}{l}\text { EU SF } \\
\text { ('Effective PA') }\end{array}$ & 7 \\
\hline $\begin{array}{l}\text { Analytico- } \\
\text { Methodological Unit }\end{array}$ & $\begin{array}{l}\text { Interior } \\
\text { (Mol) }\end{array}$ & 2016 & $\begin{array}{l}\text { yes } \\
\text { (est. 2013) }\end{array}$ & $\begin{array}{l}\text { OECD + } \\
\text { EU SF } \\
\text { ('Effective PA') }\end{array}$ & 10 \\
\hline $\begin{array}{l}\text { Institute of Health Policy } \\
\text { (IZP) }\end{array}$ & $\begin{array}{l}\text { Health } \\
(\mathrm{MoH})\end{array}$ & 2016 & $\begin{array}{l}\text { Strategy Unit } \\
\text { (est. 2012) }\end{array}$ & $\begin{array}{l}\text { EU SF } \\
\text { ('Effective PA') }\end{array}$ & $8+4$ \\
\hline Institute of Social Policy & $\begin{array}{l}\text { Labour, Social } \\
\text { Affairs and Family } \\
\text { (MoL) }\end{array}$ & Feb. 2017 & $\begin{array}{l}\text { Institute of } \\
\text { Social Policy } \\
\text { (2003-2006), } \\
\text { Analytical Centre, } \\
\text { (est. 2010) }\end{array}$ & $\begin{array}{l}\text { EU SF } \\
\text { ('Effective PA') }\end{array}$ & 6 \\
\hline $\begin{array}{l}\text { Institute of Cultural } \\
\text { Policy (IKP) }\end{array}$ & $\begin{array}{l}\text { Culture } \\
\text { (MoC) }\end{array}$ & Nov. 2017 & no & $\begin{array}{l}\text { EU SF } \\
\text { ('Effective PA') }\end{array}$ & 0.5 \\
\hline $\begin{array}{l}\text { Institute of Agricultural } \\
\text { Policy }\end{array}$ & $\begin{array}{l}\text { Agriculture } \\
(\mathrm{MoA})\end{array}$ & Nov. 2017 & no & $\begin{array}{l}\text { EU SF } \\
\text { ('Effective PA') }\end{array}$ & 0.5 \\
\hline
\end{tabular}

Notes:

${ }^{1}$ In all cases, except for the Government Office, these are ministries (i.e., 'Ministry of ...').

'UAP was established in 1992, with the grounding of the Slovak ministry, as a replication of a similar Czecho-Slovakfederal body (Slovak

Republic became independent 1 January 1993).

${ }^{3}$ Effectively disempowered, and ceasing to exist as a distinct unit, by merger with a hierarchically lower organisational unit.

${ }^{4}$ 'Yes' means that the AC was established through restructuring of existing units.

$5^{\prime} E U$ SF'stands for European Union's Structural Funds. 
- the first analytical centre established in 2003 and serving as a hub in the current network of analytical centres - came to be perceived as an independent authority able to speak to politicians on eye level and even oppose already-formed policy decisions. This function of 'speaking truth to power' has thus started to be perceived as a model to be replicated throughout the whole executive. Lately, the IFP relabelled and promoted its approach to the technical expert advice as 'value for money' (discussed in The Best of Possible Worlds, Filko et al., 2016, on the basis of the pilot case studies conducted by the IFP). Over 2015-2016, the public discourse on 'value for money' was affected by the tragic passing of the IFP director and its main initiator; this resulted in a further increase in the popularity of the idea. Thanks to this momentum, efficiency and effectiveness of public programs and policies, particularly in the context of post-financial crisis, became one of the foci of the 2016 national elections.

Second, increasingly, the publicly visible staff politicisation, accompanied by corruption scandals, resulted in calls for professionalization of the civil service, both internationally from the EU (Report of EC, 2014) and the OECD (2014), and nationally. Politicisation results in high staff turnover, particularly, on the level of senior civil servants (Staroňová \& Rybár, 2018), which has implications on the capacity of public bodies to incorporate impartial expertise into existing ministerial hierarchies as well as policy processes. In this context, the establishment of highly professional analytical centres is promoted as a move towards greater professionalization of the civil service and improvement of policy making. ${ }^{9}$

Third, the substantial inflow of financial resources from the EU structural funds enabled to attract highly qualified cadres into the civil service. Since the IFP director managed to include the priority of creation of analytical centres in all kinds of strategic documents of the government and individual line ministries as well as the EU-funded Operational Programme Effective Public Administration (May 2016 - December 2020), the latter framing projects covering the analysts' above-average salaries, thus enabling to recruit from among graduates of prestigious foreign universities, academia, research centres, think tanks and the like, as well as training and internship opportunities. ${ }^{10}$ The position of an analyst is the most frequent position in analytical centres, ${ }^{11}$ complemented by secretarial, project management or data processing staff - with all staff possessing civil servant status (rather than being political appointees or short-term advisors).

\section{METHOD}

For this research, we utilised qualitative in-depth interviews as well as complementary document analysis. Between September and December 2017, we conducted a series of semi-structured expert interviews with the heads of analytical centres, originally as part of a wider research project examining politico-administrative relations. Our interviews covered 14 out of the 15 analytical centres: ten of these were established (from the ground up or through restructuring) in wave 4, out of which two are in the process of being set up $(\mathrm{MoC}, \mathrm{MoA})$, three have undergone a merger with another unit/organization, which meant a de facto termination of the ACs (MoD, MoT and very recently MoEdu), and two were not established in the fourth wave but are surviving since $1990 \mathrm{~s}$ (MoFA, MoF).

The interviews were conducted in person, after obtaining informed consent, and lasted between 60 and 90 minutes. They focused on topics including everyday managerial and other practices of directors' work, understandings of 'analysis' as a task and competence, ensuring and perceiving output quality, institutionalisation of the analytical centres, role in policy processes, as well as interaction with stakeholders within and outside of their ministries. The interviews were transcribed and analysed following the methods of iterative coding (Miles \& Huberman, 1994) and qualitative content analysis after Meuser and Nagel (2005). The statements by interview partners were anonymised, and we label the interviews chronologically.

9 For example, The National Program of Reforms in Slovakia, approved by the government resolution No. 195, 23 April 2014, highlights the need and goal to 'strengthen and improve analytical capacity of civil service'.

10 The eligibility criterion for training institution is top placement in the Shanghai Academic Ranking of World Universities and/or in RePEc, ranking of economic institutions.

11 Job advertisements for the position of an analyst in ACs are promoted differently than openings for regular civil service positions. Analyst positions are advertised regularly primarily through social media networks, professional platforms and LEAF organization, which attracts graduates from foreign universities back to Slovakia as opposed to internal or official web sites of the PA organization. Typically, the advertisement looks for a person who has mastered 'quantitative methods, econometrics, statistics, databases and has high analytical skills', with the workplace being described as a 'young dynamic team' (IFP's Facebook page, December 2017). IFP manages a database of all successful candidates and shares it with the rest of ACs. 
To obtain complementary information on the mission, vision and goals of the analytical centres, as well as their institutional stabilisation (framework for creation, embedding in the organisational structure, financing) and outputs, we - guided by cues in the interviews - turned to government documents, official web pages of the line ministries and respective ACs, project documentation, social media activity, published analyses, as well as news. We also conducted complementary interviews with several well-informed persons from within the line ministries (a former minister, an advisor and senior civil servants) in order to reconstruct the earlier waves of ACs' establishment.

Several objectives were guiding our interpretation. Central was the reconstruction of an intersubjective account central to the work of organising on which the ACs and their staff, as well as their patrons participate. Complementary to this, we focused on other aspects through which the technocratic 'mode of governing' is made possible. These included the persons and materials participating on this work of organising (examining the intersubjectively shared elements of analysts' community and culture, but also including the subjectivities of individuals), as well as looking at the constitution of the interface between 'politics' and 'expertise' as a continuous achievement.

In studies of policy or governing, 'accounts' belong to interpretive policy analysis and are broadly related to theoretical concepts such as 'stories', 'narratives', or '(discursive) frames'. Although avoiding providing a precise theoretical definition, Colebatch (2010) understands accounts as helping practitioners make sense of the tasks at hand, solve practical dilemmas and guide action. There are always multiple accounts 'in circulation', and it would seem that neither of these accounts - taken in isolation - is able to fully or sufficiently explain policy. Colebatch (ibid.) recognises three distinct yet overlapping accounts of policy. The 'official' account of policy as authoritative choice provides a 'sacred' 'public performance' of decisions and decision makers, often constructed through 'backward mapping' of policy decisions. The 'insider' account of policy as structured interaction, often gleaned through informal debates with practitioners, provides a more 'profane' counter-account of policy as management of fields of concern and a complex process of stakeholder interaction. These two accounts are, in some aspects, reformulations of the symbolic 'front-stage' and pragmatic 'back-stage' of institutionalised social life - although, as Colebatch (2017, p. 7) notes, the significance of this distinction, and, we might add, their tense relationship, 'for systematic modelling of governing is less well understood'. Lastly, the account of policy as social construction is concerned with the terrain of the previous two accounts, that is, with problem framing and related definition of stakeholder roles and shared norms, and thus provides what could be called a meta-account. In his contribution to the previous CEJPP issue, Colebatch's brings up this notion as the context to which the articulated account needs to be appropriate, or the situation to which the discourse conducted must match. (And, we might add, paraphrasing Rose \& Miller paraphrasing Nietzsche, the action of articulation and its context are bound by a 'will to make sense of'.) The focus on accounts decentres the government as a monolithic entity, viewing it as an arena instead (cf. state apparatuses in Poulantzas, 2010, p. 133-134). 'Policy' is seen as a specific form of governing, or more precisely, 'as a particular discourse mobilised in both the accomplishment and the explanation of governing' (Colebatch, 2017, p. 3), legitimating public action through varying combinations of authority, order, and problematisation. The workings and performance of governing are viewed differently by different actors, putting some of these aspects above the others (ibid., p. 7).

Methodologically, we encountered numerous local, concrete accounts sharing stark similarities on a number of issues (or 'topoi'), as well as in regard to structural features (relationships between issues). Building on these similarities, we constructed an overarching, somewhat abstracted 'categorical' account, which we present in the next section. We also note where we find local distinctions or variations relevant.

\section{ESTABLISHING INSTITUTIONALISED EXPERTISE: FINDINGS}

This section presents our findings, which are structured into four areas: (i) the vision of governing in the account that serves as a central axis of the 'mode of governing' manifested by the analytical centres, (ii) the transposition on the subjectivities of an analyst, focusing on motivation and expertise, (iii) analysts as a distinct professional group and organisational subculture, and (iv) boundary work in the terrain where impartial expertise and politics meet. 


\section{Vision of governing with analytical expertise}

When researching Western PA organisations, scholars might expect to find a documented vision or mission statement ('frontstage'), as well as a reified reflection on lived values and purpose ('backstage'). In the CEE countries, the situation is somewhat different. Public administration organisations in the region have undergone New Public Management (NPM) reforms, with main focus on agencification and/or output orientation (Randma Liiv \& Drechsler, 2017), while - puzzlingly - mission and goal statements, especially in terms of the intended institutional outcomes, are largely absent. In Slovakia, almost none of the line ministries ${ }^{12}$ has, until these days, clearly formulated and made publicly available a mission, vision and/or goal statement. Instead, PA organisations articulate their purpose through areas of responsibility as defined by law and official statutes. What we can judge from the insider accounts, civil servants in general do not seem to possess a consistent account of the behavioural norms as well as the overall purpose and results of their work.

The analytical centres, where the directors take on a rather unusual measure of responsibility for shaping their units, are different in some important respects. First, almost every AC has a Facebook page with a clear, one-sentence mission (typically some variation of 'we aim to contribute to improve decision making of the ministry and offer to the government and the public reliable analyses and prognoses', introduce evidence-based policy making). The directors were given free hand in wording the vision, though they always consulted the minister to come to an agreed statement. Second, there is a publicly available (and, for Slovak PA, unusually easily readable) vision and mission statement in the form of the 'value for money' study (Filko et al., 2016), to which all AC directors refer to. Third, in the directors' accounts, the mission and purpose stated above (with 'creating the conditions for informed debate' at times mentioned in addition) are addressed somewhat vaguely and implicitly, while examples of specific initiatives or outputs and practical concerns take centre stage.

A number of values or principles shine through the discussion of initiatives and practical concerns. One such multi-layered cluster of principles and practices we termed (i) transparency. ACs pursue full disclosure of data and method on which analyses are based, public peer review for larger studies, as well as public accessibility of the results, including formulas for verifications. The ACs also aim to establish such practice as a norm, to help establish conditions for a reasoned, factual and non-coercive discussion, where interests are revealed and well-founded criticism - though with fairly narrowly understood validity basis grounded in econometric tools and framings - is possible (Habermas' 'ideal speech situation', 1990, p. 65-66). Transparency, therefore, for the ACs also involves transparent motives and desisting from strategic action, that is, 'no side interests' (Interview B), or 'transparency eliminates them' (pressures from interest groups, Interview C) meaning that ACs do not participate in the intra- and interorganisational politics and backroom dealings (described as "I give to you, you give to me" system - [but] we do not have anything to give', Interview A). Analysts do not strive for personal gain and do not see themselves as belonging to a (party-) political clique; the directors also give surprisingly open interviews to the media. Interestingly, this transparency leads to a collapse of the distinction between the official and the insider accounts.

Additional clusters of values and principles include: (ii) orientation on professional merit, manifested primarily through the application of econometric, analytical skills (discussed in more detail below); and (iii) voluntarism, that is, their services are offered to other organisational units without coercion and on the basis of demand ('we can assist them [other units] with lots of tasks... not by pushing, but [by] showing', Interview G). The latter ties in with (iv) conflict avoidance, as the ACs sense they cannot afford a confrontational way of communication ${ }^{13}$ and have to learn to cooperate with other ministerial units and sectoral stakeholders (" $[t]$ he key is not to get into a dispute and [instead to] explain, explain, explain.... Interview E). Lastly, the ACs favour (v) political opportunism, using political windows of opportunity (ends and beginnings of election cycles, or situations requiring the improvement of public image for individual ministries) to increase the relevance of their analyses in policy processes ('colleagues have some analyses in their drawers where not sufficient attention was paid and then periods come, for example, around elections, when you can publish things that would have maybe more difficulty to publish before', Interview A).

12 Ministry of Finance being the exception, with its goal to safeguard public finance and strive for sustainable financial balance and prosperity (http://finance.gov.sk/Default. aspx?CatID=5171, accessed 20 January 2018).

13 The IFP is an exception in this regard. The directors of other ACs seem to view IFP analysts as 'cocky' and confrontational, being 'in a different position since belonging to the Ministry of Finance'. This bull-headed attitude is seen as non-productive by the rest of the ACs in the sense that IFP does not seem to care for political feasibility - whereas they need to learn when, and in front of what audience, the voicing of criticism is appropriate, and to be able to rely on their sectoral stakeholders. 
To a significant extent, the ACs' identity in these accounts is constructed through a constitutive Other, the rest of public administration'. It is characterised by an antagonistic mode of organising, in which political appointees are interested in 'what can be earned, instead of what can be improved' (Interview B) and are closely tied to the political parties or cliques with strong links to private businesses. This mode was even explicitly termed as 'doing evil' by one of our interviewees (Interview B). Parties that do not seek any public interest but rather own profit and/or do not possess a strong vision - and without corresponding set of measures defined through own expert teams, without systematic policy (note the focus on intellectual merit) - are suspect of being a front for organised corruption. Consequently, positions responsible for procurement and EU funds are particularly 'attractive' for political nominations. The directors explain the success of the ACs also in part by the fact that they lack - and even try to avoid - any significant financial responsibilities, so politicians 'let them be' (Interview E). Through the inversion of such corrupt Other, an identity of asceticism is invoked: only through abstaining from worldly desires and material quarrels - and through confession, making one's doings fully transparent - can one put his or her labours into the service of Reason. Viewed through this lens, the analysts' mission acquires mystical properties. The next section looks at the individual transposition of this mission onto a single individual.

\section{The subjectivities of an analyst: motivation and expertise}

While the previous section described the mission, values and principles that form the foundations of the analysts' account, this section will looks at the transposition of the said mission onto a single individual, focusing in particular on individual motivation and skills. Personal motivation plays a crucial, although implicit role in the accounts expressed by the AC directors. All of the directors (and, in the view of the directors, also the analysts) are driven by a strong sense of public service and commitment to public interest they believe in it [public interest] and we have a lot of people whose approach is excellent' (Interview C). A substantial share of AC staff has experience abroad (e.g., United Kingdom, the Netherlands, Germany), bringing ideas about how a professional public administration should work, which combines with a sense of duty towards their country of origin (" [d]uring recruitment this motive of help, this internal motivation of "I want to change it", is often heard from people who have been abroad... [t] hat I was away for a long time, and want to return something back to Slovakia', Interview A).

This motivation rests, primarily, on the commitment to public interest. Most of the directors left highly paid jobs and good career prospects in the private sector in Slovakia or abroad, in order to join the Slovak civil service with low wages and bad public image (as corrupt, politicised, and inefficient). Thus, high personal costs are paid by the directors (and presumably many analysts too) as foregone opportunities. At the same time, in some of the ACs, the working times and intensity of work are extreme, while 'I would not work as hard for a private employer' (Interview A). They require, however, a large degree of institutional, managerial and financial autonomy and the ability to define and carry out their job without unnecessary restrictions or controls. ${ }^{14}$ It would seem the bad image and systemic deficiencies of the Slovak public sector actually help attract highly skilled and motivated individuals, even if they sometimes see their role as temporary.

This type of motivation can be captured by the term public sector motivation (PSM), although the willingness to endure hardship for small material gain also again brings to mind the image of an ascetic. PSM distinguishes between extrinsic motivation (such as job security, remuneration, or career opportunities) and intrinsic motivation. The latter rests on an inner sense of accomplishment, ${ }^{15}$ public duty or public interest, that is, intention 'to do good for the others and shape the wellbeing of the society' (Perry \& Hondenghem, 2008, p. 3). Civil servants across public administration traditions and countries might thus share the motivation to act (professionally, ethically, accountably...) in the public interest, as well as a public service ethos resting on some core set of civil service, or public, values (cf. Hood \& Jackson, 1991; Jørgensen \& Bozeman, 2007). Limited descriptive evidence from CEE countries indicates that

\footnotetext{
14 In fact, all interviewees claimed that should this independence be violated, their motivation to work in public service would decrease up to the point of considering leaving, which was the case of earlier mergers of the ACs with other units (MoT, MoD, and recently MoEdu). Further reasons for leaving include side-lined results, or pressure to justify decisions serving primarily for private gain.
}

15 For example, one of our interviewees desires 'to leave a legacy by building and creating an institution' (Interview $\mathrm{H}$ ). 
public service motivation is lower in these countries than elsewhere ${ }^{16}$; analytical centres might well be islands of positive deviation in this respect.

Scientific analyses are the main means through which ACs aim to increase the quality of policy making, and these require specific skills. Central are technical skills of applied quantitative data analysis, carried out in the framework of economics (such as cost-benefit analyses), tied to the ability to structure problems, ask 'the right' questions, and draw alternative solutions and conclusions in the form of policy recommendations. Analysis is a complex skill learned over time, requiring 'out of the box thinking' and the ability to examine and judge the reliability of knowledge claims. Elite education abroad is considered a strong asset, but personal characteristics such as emotional intelligence, stability, work discipline and passion were listed by the directors as perhaps even more important than technical ability. The ability to communicate and 'sell' one's own outputs and the notion of evidence-based policy making to other audiences is highly valued as well. Senior analysts are also expected to possess practical political competence to judge what kind of initiative or policy recommendation is politically feasible, and to deal with internal 'power holders'.

\section{Analytical centres as a distinct professional culture}

Focusing on individuals would deliver an incomplete picture. In this section, we focus on the social fabric in which individuals are embedded, that is, on the analytical centres as sites of a distinct professional culture. The civil service, far from monolithic, consists of a range of roles with differing identities, developed around different tasks, management styles, specific problems and concerns, differing institutional incentives, and other factors. As a large and complex organisation, the civil service thus consists of a number of 'local cultures' ${ }^{17}$ In comparison to what we would expect from the Slovak public administration (in terms of personnel composition, skills, salaries, working culture, openness), some of the characteristics of the analytical centres are quite pronounced - and many of these differences also play key roles in the centres' account.

Among the most striking features of the analytical centres are the demographic characteristics. The analytical staff in ACs, including the directors, are predominantly young males ('and then the boys from AC come up', Interview A). They come from economic or mathematical/IT educational background, mostly acquired abroad at elite universities, and possess work experience from top universities, research centres and/or government consultancies, as well as excellent command of English language. For comparison, women make up 64 per cent of the Slovak civil service. In terms of age, one half of civil servants has more than 12 years of experience in their jobs, while one third is older than 50 years, one third between 40 and 49 years, and one third between 30 and 39 years (GO, 2014), with little (if any) knowledge of English. This results in several intersecting differences - along gender, age, as well as education - from the rest of the public administration. ('People have entertaining stories about there having been two esteemed female officials and then a lot of young boys came in who thought they are going to change it and in the end they did, actually', Interview A.)

This hunger for success is also reflected in their work culture: the analysts are strongly professional and orientated on outputs and high quality. This lends itself to working long hours, in some cases (IFP, IHP), this up to a point of seriously affecting the private lives of analysts - even though long hours are formally not expected and 'they can go home whenever the work is done'. They also tend to see themselves as the only truly hardworking, competent and creative group of civil servants in the whole of public administration. (Nevertheless, this view seems characteristic especially of the IFP and seems to soften with experience of collaboration with other ministerial units for other ACs. Some directors start to value the competency of other units - 'we might have better analytical skills, but they have the experience and institutional memory and know a lot, you just have to ask them rightly,' Interview J - or understand that hardworking cultures exist also elsewhere).

\footnotetext{
16 A comparative quantitative research on public service motivation among 38 countries of the world included 8 CEE countries, of which 6 ranked in the 10 lowest scoring countries, including Slovakia (Vandenabeele \& Van de Walle, 2008). Randma-Liiv \& Drechsler (2017, p. 601) arrive to a similar conclusion in their account of PA reforms in CEE countries in the past 25 years by stating that there is an 'insufficient formal or informal framework of professionalism which might provide an esprit de corps or any other kind of common identification or loyalty'.

17 ' $[\mathrm{A}]$ more realistic view [on large, complex organisations] may be one that considers organizations as minisocieties, multicultural in nature, each with distinctive, competing, and potentially conflicting local cultures formed along functional lines, shared fate, professional occupation, ethnic background, or job rank' (Alavi et al., 2006, p. 196).
} 
The centrality of expertise in the analysts' culture thus also expresses as a hierarchy of expertise, which is both individual (since analysts possess the ability to judge individual's skills on the basis of how analytical and associated tasks are approached), as well as organisational (analysts informally rank other departments, as well as the ACs and similar institutes abroad). In the analysts' culture, expertise generates trust (this explains the emphasis on own testing of potential candidates), while, as we have indicated, lack of expertise generates distrust. Trust functionally enables mutual learning among ACs as well as from external (international) organisations with high analytical competence.

Speaking of expertise, the directors informally classify their personnel into several roles and tasks. ${ }^{18}$ 'Pure' - junior and senior - analysts (or 'small scientists') need to be highly versed in quantitative methods and conduct strongly academic type of work ('honest neutral work, where the methods and data sources are verifiable, Interview D). They need to specialise on specific problem areas, and most of the directors stressed that with small staff there is a risk that some problem areas in the given policy sector might stay 'without coverage. Pure analysts are also seen as requiring isolation or protection from external pressures. Furthermore, each AC has one or two staff conducting more managerial and 'operative' tasks, including communication of outputs, commenting on legislative and strategic proposals and interaction with internal and external stakeholders. This role is often fulfilled by the director, or a person very close to him or her, and is associated with senior status and also additional areas of competence (including communication, management skills, experience in dealing with stakeholders in public administration). Further - less prestigious and visible - roles include administration (possibly including database input), statisticians or staff focusing on data collection, ${ }^{19}$ and in some of the ACs one or two staff with substantive (as opposed to econometric) expertise, for example, a geologist at the Institute of Environmental Policy or a sociologist at the Institute of Social Policy, or a lawyer. In some of the ACs, also IT-personnel or students of IT/mathematics faculties (e.g., as internship) are to be found.

Some of the ACs' work is seen as patching up of missing elementary competence in other parts of public administration, particularly in the quality of evidence and data provided, analytical and quantitative skills but also in basic routine administrative support: 'So when I think about it, a large part of the work done by AC would not have to exist, if the officials would do [theirs] properly.' (Interview A). Some of the first tasks the ACs tackle in their line ministries is to improve the availability and quality of quantitative data. It is therefore far from surprising that ACs' expert ethos clashes with the norms, procedures and professional standards in the civil service. The analysts' account of the larger administrative culture in which they, as described above, see themselves as a pure and embattled minority, tells of 'keeping secrets', red tape, obstinacy and inability of practical action. The frustration experienced by the AC directors is visible in HR management. Standard recruitment procedures do not allow for testing of applicants' competence in the area of analytical skills, so all of the ACs' directors use their own (or IFP-originated) tests and standards for recruitment. They would also frequently bypass the standard contracting, salary schemes and training in order to increase flexibility and attractiveness to private sector candidates ('I choose for my staff whom I want and the salary range offered', Interview E), and, similarly, formal work rules (such as leave of absence or dressing smart) are considered much less relevant than producing quality output. Directors seek guarantees of 'absolute freedom'; most of our interviewees negotiated some kind of agreement with their patrons (politicians or high-level political appointees) that secured freedoms not common in - and sometimes viewed with dismay by - the rest of the civil service; literature describes such developments under the term 'functional politicisation'. This institutional autonomy extends beyond HR management and office rules to freedom of autonomous external communication and agenda setting for analyses (see also below).

Shared competence and disciplinary outlook of the analysts form, along with their values and ethos, work practices, vocabularies, ${ }^{20}$ genres of documentation, symbols and artefacts, ${ }^{21}$ spaces, ${ }^{22}$ and socioeconomic and demographic characteristics as well as lifestyles, a 'local' public administration culture or 'organisational subculture'. Van Maanen \& Barley (1985, p. 38) define subculture as a 'subset

18 There are small variations across the ACs in respect to the following roles. Nevertheless, such role classifications can be found neither anywhere else within the civil service as far as we know, nor in the Civil Service Law.

19 As indicated above, data collection and digitalisation of paper data are perceived as a burden or job that other units should be doing.

20 Including specific humour shared across the ACs ('we're weird').

21 Among the symbolic 'organisers' that enact a boundary to the rest of their ministries and develop a shared image across the ACs, are own logos (incorporating a chart as a visual element), titles ('Institute of [sectoral] Policy') and acronyms.

22 In several cases, the physical location of the AC separates them from the rest of the ministry ('us in this building', or 'us at the end of the corridor'). 
of an organization's members who interact regularly with one another, identify themselves as a distinct group within the organization, share a set of problems commonly defined to be the problems of all, and routinely take action on the basis of collective understandings unique to the group', a definition which the analysts fulfil very well. Utilising the typology of organisational subcultures ${ }^{23}$ developed by Martin \& Siehl (1983), it can be considered a 'counterculture', since its intention is to transform the dominant system and is (especially the most visible IFP, with its confrontational attitude) even perceived as a threat. ${ }^{24}$ 'Among the officials we have such boys who think they understand everything. They come and start to disturb the system.' (Interview A)

\section{The boundary between impartial policy advice and politicisation}

Analysts see their mission in the provision of neutral, objective analytical evidence for informed decision making ('facts instead of opinions, emotions, personal experiences', Interview A). Several scientific standards apply to this 'honest academic work', such as formulation of objectives and research questions, identification of data, usage of reliable methods, verifiability of analysis and interpretation, and the ultimate test of peer review by fellow analysts. Scientific policy advice conceived in this manner is considered apolitical (in the sense of party politics as well as ideological stances), and personal political orientation is considered distinct from and irrelevant for factual expertise: 'I am not political, I look at things from the perspective of expertise' (Interview D).

Freedom from political influence and institutional autonomy are seen as necessary requirements for conducting policy advice. The directors hold the view that whenever ministers would seek to use analytical centres symbolically, to increase policy legitimacy (cf. Cash et al., 2003; Bosswell, 2009), doing so would compromise the integrity of their analyses. In this account, past incarnations of analytical centres are painted as negative examples. 'Head of AC at the Ministry of [...] was too close to the political party, [so] naturally the incoming new party viewed him not as a professional but as political. Through an organizational change they merged the AC with another unit.' (Interview J). A merger with a different organisational unit is seen as a constant threat. ${ }^{25}$ 'The worst case scenario is to be completely ignored... public pressure is already big enough so [the minister] cannot terminate [the AC] but can isolate it completely so that it ceases to have any influence and [subsequently the analysts] leave on they own. And it did happen on several occasions.' (Interview I)

Freedom to, at least partially, determine their own agenda priorities and topics - and not only on the basis of demand by politicians, high-level civil servants, and other organisational units - is considered important ('the [minister] has to trust us', Interview E). ${ }^{26}$ It is so extensive, that 'some [analytical centres] are still searching for themselves' (Interview H). The political heads of the ministry are involved in topic determination (i.e., along the main priorities of the current government or ministry), while the capacity for studies is also affected by ACs' personnel scarcities, but the ACs can also conduct studies that 'are fun', 'value for money studies [conceived] by the IFP', as well as fringe stuff. We have not encountered a single case where a minister would overrule such a study direction. Institutional autonomy is also linked to personal motivation in that political interference would lead to analysts' resignations and perceived failure in the mission of the analytical centre - 'if I felt any political pressure, I am leaving immediately' (Interview J).

Yet no clear, inherent boundary at which political interference begins and ends exists. In numerous aspects of analysts' work, politics cannot be entirely bracketed, and the boundary between politics and impartial scientific expertise needs to be continuously constructed. Importantly, the very nature of policy advice structures the decision space and prefigures, for involved actors, ways of acting. 'We are drafting the options from among which politicians choose. That is a decisive instrument.' (Interview A) Advisory centres attempt to draft decisions such as to constrain the discretionary power of managers of subordinated units; the project of transforming of public administration and governance is conducted according to the will of those belonging to the exclusive club of analysts or

23 Martin \& Siehl (1983) recognise 'enhancing subcultures' (enthusiastically committed to organisational values), 'orthogonal subcultures' (holding also peripheral values but largely committed to organisational values, not threatening to the overarching culture), and 'countercultures' (defined through opposition to the core values of the dominant culture and threatening to the overarching culture).

24 This subcultural character has also been recognised by some of the media, likening the analysts to 'hipsters' (Múčka, 2014).

25 This is a real threat, for example, on 1 January 2018, the Institute for Educational Policy (MoEdu) has been, without any prior warning or substantive ex post justification, by the decree of the Minister merged with another section and its director was made redundant.

26 Independence is usually not discussed as a civil service value. Quite on the contrary, professionalism of civil servants rests on executing the will of the politicians what academic literature refers to as 'responsive competency'. 
possessing sufficient levels of expertise to participate. The political dimension of analysts' own work in the sense of reallocation resources between policy actors or between stakeholders is not acknowledged: the analysts 'improve' or 'optimise'.

Academic discussions on 'boundary work' find that even the most obviously technocratic and impartial scientific advice is frequently loaded with value judgements - judgements resulting in the prioritisation of relevance of individual facts or disciplines, inclusion or exclusion of viewpoints, determination which questions are answerable and what knowledge is available (Jasanoff, 1990). Our interviewees view themselves as enlightened elite, preferring authoritative decisions implementing 'the ideal' or optimum dictated by 'objective' econometric models (the models speak with the Voice of God, but for its channelling and interpretation, the gift of arcane oracular competence is required) to democratic and participatory decision making. Nevertheless, we can also confirm that behind the mantle of objective expertise occurs also arbitrary adjustment of criteria or even educated guesses. Such an adjustment moves the results away from 'the ideal' or 'pure technocratic optimum' towards results that are more acceptable to important stakeholders (goal of securing cooperation) or results that more strongly reflect specific values such as solidarity or accessibility of services.

As senior analysts and directors acquire political skill, they learn to adjust their analyses to political realities. 'You can have the best analysis but if [they are considered] not relevant and [achieve] no impact, then you cannot expect success' (Interview B). This includes timing their less 'sexy' analyses - that is, analyses on policy problems or suggesting solutions that are thematically less attractive to politicians and their voter constituencies - in respect to election cycles. (Nevertheless, the understanding of what constitutes analysis in a political setting seems to differ across the ACs.) Another dimension, indicated immediately above, concerns policy actors. The most mature ACs recognise that policy advice is not simply a matter of speaking truth to power but should also rest on the ability to know when to criticise and in front of what audience. 'The director of an analytical unit should be somewhere halfway ... He should be able to read those academic papers, direct his colleagues and challenge them.... [A]t the same time, he needs to be a good manager and understand what is politics, how he operates in that system.' (Interview A)

Lastly, the focus on economic tools and dominance of econometrics as a form of knowledge ('I cannot imagine analysis without quantification', Interview A) constrains the possibility of drawing insights from other disciplines and pursuing a multidisciplinary approach. ACs at times attempt to integrate other forms of knowledge (such as local/lay knowledge of stakeholders in municipalities or hospitals, embodied knowledge of patients, political and tacit knowledge of fellow civil servants) - although such practice is far from standard. Such forms of knowledge, however, either require translation into the language of econometrics, or become grounds for the arbitrary adjustments just described, with the inescapable tainting of the purity of evidence and resignation on the 'technocratic ideal'. Uninitiated laics are far too crude to grasp the divine language; to them, the crystalline beauty of the architecture of Creation shall remain forever shrouded.

\section{CONCLUSION: TRANSFORMING PUBLIC ADMINISTRATION AS A STRATEGY}

In the first two decades after the fall of Communism, the societal status and employee attractiveness of civil service (and the public sector in general) have worsened considerably in the CEE. Paradoxically, this decline offers a fertile ground for highly motivated and skilled individuals with value orientation on public wellbeing. The establishment of 'analytical centres' at all line ministries (and other crucial institutions) is a significant undertaking, binding a number of such individuals through a shared account of transforming Slovakia’s politicised or plain corrupt governing practice through providing scientific policy advice.

This undertaking is complex and takes place at several levels at once. It obviously includes formal institutions and their transformation (in terms of autonomous organisational structure, financing through projects, as well as cleverly anchoring conditions for future institutional development in various documents of the government). Nevertheless, institutional reform tells the lesser part of the story. Other levels, which in this case seem to possess higher explanatory power, include culture (the establishment of analysts' counterculture, Othering the dominant civil service culture), informal institutions and practices of organising and governing (external communication, interaction with internal stakeholders, HR management, office rules), as well as development of networks (that include the OECD, European Commission, academic community, or enlightened public) that provide external legitimacy. The account of governing through scientific policy advice is a pivotal element keeping these levels in sync. The account offers key references for construction of personal identity as well as external perceptions, while at the same time providing a set of principles and values that guide the work of everyday as well as strategic organising and enable dealing with the dilemmas of the work of governing 
on the boundary of impartial expertise and politics. The account, a key 'organiser', acts as an internal gel that co-ordinates and harmonises the various levels of this project of transformation.

Several aspects of this account are of interest. First, it is markedly at odds with the simple picture of hierarchical, legal-rational authority CEE countries have as a model of governing in the West. Second, it marries the characteristics of the official account of policy as authoritative choice with the insider account of policy as structured interaction: since the public appearances of ACs directors are characterised by unparalleled honesty and openness, and the published materials contain extensive argumentation and reasoning, the official and insider accounts have a significant overlap. ${ }^{27}$ Whether the principle of transparency implies constructing a somewhat homogeneous audience, is however, open to further analysis. Third, the account provides a practical guidance to cope with a significant internal contradiction of the ACs resting in the fact that although they perceive the current practices of public administration as politicised, they themselves are willing to bend the rules both in their work of organising ('functional politicisation') as well as analyses. The resolution of this contradiction rests on an appeal to expertise in the service of the greater good, a value constructed and upheld through the account. In this manner, the account serves in a role similar to organisational and policy 'myths' (Yanow, 1996).

Said undertaking of transforming the Slovak public administration also follows an intentional strategy unfolding through a series of stages. Broadly, the first stage consisted of the establishment of the IFP as a hub of the future network, strategically placed in the Ministry of Finance. After proving the ability to survive several election cycles and maintain relations to changing political patrons, a larger project of replicating the IFP model into line ministries is formulated and seeds of future success (in formally anchoring the ACs in national and international documents) are sown. Success will have rested especially on (i) control over ACs' financial performance staying in the hands of the IFP (thanks to funding through projects), (ii) the development of an informal network and community of academically-proven economists serving as a pool of potential candidates (for example, several of the ACs' directors have worked at the IFP) and the breeding ground of analysts as a distinct subculture, as well as (iii) formulating and disseminating the vision of governing through expertise, showcased on selected success cases (such as Filko et al., 2016). The current, third stage forms the yearly years of ACs' implementation, in which mutual learning between the ACs, a shared external image and mobilisation of public and expert support are important. Importantly, a certain 'hybridisation' occurs in the course of this stage. ACs develop political competence and build intra-ministerial networks, but also take over some norms and practices from their immediate organisational environment into their organisational culture, while somewhat softening the oppositional relation to the rest of public administration and losing some of their elite self-perception. The fourth stage shall unfold once the value of the ACs' approach proves itself in practice and sufficient numbers of internal stakeholders are won over to the idea. Analytical capacity will spill over into the substantive sections of the ministries and its subordinate organisations and cease, largely, to be the domain of a narrow elite ('the future is that analysts will be integrated everywhere so that $A C$, if still in place, would do only very technical part, such as modelling,' Interview E). The ACs will have contributed to the growth of supportive public audience as well as cultivation of appropriate internal partners - with generational exchange and growing public image of the public sector playing their contributing roles. It can be expected that by that point the prime movers, the highly motivated and skilled individuals behind the earlier stages, will either have adopted high positions in the civil service and/or politics or left. What had once been a counterculture will have become the new norm.

One of the most curious factors in this whole story is political will, that is, the support of patrons - politicians or high-level political nominees - who, although coming from parties associated with patronage and corruption, create conditions under which this unique project can (perhaps temporarily) thrive. ("The minister is old school (...) but now huge progress is made because of the state secretary,' Interview C). Several of our interviewees think that the need to improve public image of specific sectors and a publicly expressed need for reforms opens windows of opportunity, which the IFP, with its institutional blueprint, access to resources and clear vision, is able to utilise. Throwing more light on this aspect would require additional research.

Technocracy, in its expression of a political pathology, has frequently been likened to a priesthood with access to highly specialised knowledge (Mannheim, 1936[1997]; cf. Gunnell, 1982; Wallace, 1996). Venturing somewhat into the territory of an anthropology of governing, we painted the analysts also as chaste ascetics, purifying themselves of worldly interests and composing a brotherhood of mystics, holding the keys to the interpretation of arcane econometric models, the sole language able to express the ultimate

27 An analysis focused more on the 'micro level' aspects of practice, including its participants and sites, would perhaps be able to offer further insights on translations and coordination between these two types of accounts, particularly on the micro-processes of production and negotiation of 'officialdom' across various practices. 
Truth of the Creation. Strengthening these notions is also the eschatological opposition between the Good pursued by the few, beleaguered initiated and the Evil of the politics-cum-private interest that befalls en masse the battlefield of public administration - an opposition conferring levels of motivation and self-sacrifice typically reserved to religious zeal. Instead of a slavish, formal adherence to a few sacred texts, mystics attempt become the living embodiment of the practice they preach. As such, they require audience to their practice, and the longing for confession ('we openly admit our mistakes', Interview A) narrows the gap between the official ('front-stage') and insider ('back-stage') accounts. Referring to Bourdieu (1971), who among the ideal-typical actors of the religious field recognises priests, prophets, sorcerers and the public ('laics'), the analysts' counterculture, donning the mantle of a small, fervent group of religious reformists, is described best as prophets (cf. also the distinction between power-tempted 'technocrats' and intellectually chaste 'monks' in Martin, 1969). Where priests 'dominate the field, control its institutions, hold the gross of its capital, and thus represent orthodoxy,' (Schäfer, 2004, p. 194), the prophets constitute their marginalised, heterodox counterparts, organised 'from below'. Importantly, priests and prophets share the interest of achieving hegemony over the field, and thus each organise around a totalising account offering a teleological harmony (ibid.). This seems to fit well: despite science and technology (including techniques of econometric analysis) claiming to dissolve ideology, these put forth 'a new legitimating ideology that subtly masks other forms of social domination' (Gunnell, 1982, p. 397).

Shortly after the collapse of CEE Communist regimes, Wallace (1996, p. 316), among others, saw the necessity of 'educating an emerging intellectual class from those countries' ${ }^{28}$ and using the immense laboratory of the post-socialist world as a field for study'. This task seems to have met with (albeit geographically limited) success and might bear its fruit in the recasting of politicoadministrative relations and a fundamental shift in the mode of governing. One wonders if this is still part of the intended experiment.

\section{ACKNOWLEDGEMENTS}

The research for this paper was supported by the Slovak Agency for Support of Research and Development (APVV) under the contract No. APVV-0880-12 'Knowledge Utilization in the Production of Policy Documents in the Policy Process'. The authors would like to thank all the interviewers for their insightful comments. In addition, this article would not have been written were it not for Hal Colebatch, whose personal initiative as well as the account-centred perspective on policy motivated our research.

\section{REFERENCES}

Alavi, M., Kayworth, T.R., \& Leidner, D.E. (2006). An empirical examination of the influence of organizational culture on knowledge management practices. Journal of Management Information Systems, 22(3), 191-224.

Boswell, C. (2009). The political uses of expert knowledge: Immigration policy and social research. Cambridge University Press.

Bourdieu, P. (1971). Une interpretation de la théorie de la religion selon Max Weber. Archives européennes de sociologie, 12(1), 3-21.

Bressers, D., van Twist, M.J.W., van der Steen, M.A., \& Schulz, J.M. (2018). The contested autonomy of policy advisory bodies: the tradeoff between autonomy and control of policy advisory bodies in the Netherlands, the United Kingdom, and Sweden. In E. Ongaro \& S. Van Thiel (Eds.), The Palgrave Handbook of Public Administration and Management in Europe (pp. 1189-1211). London: Palgrave Macmillan.

Bristow, D., Carter, L., \& Martin S. (2015). Using evidence to improve policy and practice: the UK What Works Centres. Contemporary Social Science, 10(2), 126-137.
Cash, D., Clark, W., Alcock, F., Dickson, N., Eckley, N., \& Jäger, J. (2003). Salience, credibility, legitimacy and boundaries: linking research, assessment and decision making. KSG Working Paper Series. Harvard University.

Cobarzan, B. (2008). Special advisors to the minister in Romania: carriers of political and administrative roles. In B. Connaughton, G. Sootla, \& G. Peters (Eds.), Politico-Administrative Relations at the Centre: Actors, Structures and Processes Supporting the Core Executive (pp. 293-307). Bratislava: NISPAcee Press.

Colebatch, H.K. (2017). Policy, learning and regime change: Western concepts and CEE experience. Central European Journal of Public Policy, 11(2), 2-10.

Colebatch, H.K. (2010) Giving accounts of policy work. In H.K. Colebatch, R. Hoppe, \& M. Noordegraaf (Eds.), Working for Policy (pp. 31-43). Amsterdam: Amsterdam University Press.

Craft, J., \& Howlett, M. (2013). The dual dynamics of policy advisory systems: the impact of externalization and politicization on policy advice. Policy and Society, 32(3), 187-197. 
Craft, J., \& Wilder, M. (2017). Catching a second wave: context and compatibility in advisory system dynamics. Policy Studies Journal, 45(1), 215-239.

Crowley, K., \& Head, B. (2017). Expert advisory councils in the policy system. In M. Brans, I. Geva-May, \& M. Howlett (Eds.), Routledge Handbook of Comparative Policy Analysis (pp. 181-198). NY and London: Routledge.

Dimitrova, A. L. (2010). The new member states of the EU in the aftermath of enlargement: Do new European rules remain empty shells? Journal of European Public Policy, 17(1), 137-148.

European Commission (2012). Position of the Commission Services on the Development of Partnership Agreement and Programs in Slovakia for the Period 2014 - 2020. Retrieved from http://www.nsrr.sk/sk/programoveobdobie-2014---2020/pozicny-dokument-europskej-komisie-kpartnerskej-dohode-a-programom-sr-na-roky-2014---2020/ (accessed 10 January 2018)

Falkner, G., \& Treib, O. (2008). Three worlds of compliance or four? The EU-15 compared to new member states. JCMS: Journal of Common Market Studies, 46(2), 293-313.

Filko, M., Kiss, Š., \& Ódor, L'. (2016). Najlepší z možných svetov: Hodnota za peniaze v slovenskej verejnej politike [The Best of Possible Worlds: Value for Money in Slovak Public Policy]. Bratislava: Ministerstvo financií SR.

Gajduschek, G. (2007). Socialist and post-socialist civil service in Hungary. In A. Jakab, P. Takács, A.F. Tatham (Eds.), The Transformation of the Hungarian Legal Order 1985-2005: Transition to the Rule of Law and Accession to the European Union (pp. 123-126). Alphen aan den Rijn: Kluwer Law International.

Government Office of the Slovak Republic (2014). Civil Service in 2013. Report from the Survey among Civil Service. Bratislava: Government Office of the Slovak Republic.

Grzymala-Busse, A. (2010). The best laid plans: the impact of informal rules on formal institutions in transitional regimes. Studies in Comparative International Development, 45(3), 311-333.

Gunnell, J.G. (1982). The technocratic image and the theory of technocracy. Technology and Culture, 23(3), 392-416.

Habermas, J. (1990). Moral Consciousness and Communicative Action. Cambridge: MIT Press.

Halligan, J. (1995). Policy advice and the public service. In B.G. Peters, \& D.J. Savoie (Eds.), Governance in a changing environment (pp. 138-172). Montreal and Kingston: McGill-Queen's University Press.

Hood, C., \& Jackson, M. W. (1991). Administrative argument. Aldershot: Dartmouth.

Howlett, M. (2013). Policy work, policy advisory systems and politicization. Central European Journal of Public Policy, 7(1), 4-7.

Jasanoff, S. (1990). The Fifth Branch. Cambridge: Harvard University Press.

Jørgensen, T. B., \& Bozeman, B. (2007). Public values: an inventory. Administration \& Society, 39(3), 354-381.

Keris, M. (2008). Ministerial advisors in Estonia: role perceptions as multifunctionalism. In B. Connaughton, G. Sootla, \& G. Peters (Eds.),
Politico-Administrative Relations at the Centre: Actors, Structures and Processes Supporting the Core Executive (pp. 206-224). Bratislava: NISPAcee Press.

Majcherkiewicz, T. (2008). Between the pool of spoils and shallow professionalism: recruitment, composition and functioning of the political cabinets of prime ministers and ministers in Poland 1997-2006. In B. Connaughton, G. Sootla, \& G. Peters (Eds.), Politico-Administrative Relations at the Centre: Actors, Structures and Processes Supporting the Core Executive (pp. 268-292). Bratislava: NISPAcee Press.

Majone, G. (1989). Evidence, Argument and Persuasion in the Policy Process. Connecticut: Yale University Press.

Mannheim, K. (1936[1997]). The sociological problem of the 'intelligentsia'. In: Ideology and utopia: collected works of Karl Mannheim (pp. 136-145). Vol. 1. New York: Routledge.

Martin, D. (1969). The dissolution of the monasteries. In D. Martin (Ed.), Anarchy and Culture: The Problem of the Contemporary University. London: Taylor \& Francis.

Martin, J., \& Siehl, C. (1983). Organizational culture and counterculture: an uneasy symbiosis. Organizational dynamics, 12(2), 52-64.

Meuser, M., \& Nagel, U. (2005). ExpertInneninterviews - vielfach erprobt, wenig bedacht. Ein Beitrag zur qualitativen Methodendiskussion. In A. Bogner, B. Littig, \& W. Menz (Eds.), Das Experteninterview - Theorie, Methoden, Anwendung (pp. 71-93). $2^{\text {nd }}$ ed. Opladen: Leske + Budrich.

Meyer-Sahling, J-H., \& Veen, T. (2012). Governing the post-communist state: government alternation and senior civil service politicisation in Central and Eastern Europe. East European Politics, 28(1), 4-22.

Miles, M.B., \& Huberman, A.M. (1994). Qualitative Data Analysis. London: Sage Publications.

Múčka, F. (2014, 24 November). Ked'naši hipsteri robia policy [When our hipsters conduct policy]. Týždeň. Retrieved from https://www.tyzden. sk/nazory/24097/ked-nasi-hipsteri-robia-policyl (accessed 16 February 2018).

OECD (2014). Slovak Republic. Developing a Sustainable Strategic Framework for Public Administration Reform. Paris: OECD. Retrieved from http://www.oecd-ilibrary.org/governance/slovak-republic-developinga-sustainable-strategic-framework-for-public-administrationreform_9789264212640-en (accessed 16 February 2018).

OECD (2017). Policy Advisory Systems: Supporting Good Governance and Sound Public Decision Making. Paris: OECD.

Perry, J.L., \& Hondeghem, A. (2008). Building theory and empirical evidence about public service motivation. International Public Management Journal, 11(1), 3-12.

Perry, J.L., Hondeghem, A., \& Wise, L.R. (2010). Revisiting the motivational bases of public service: twenty years of research and an agenda for the future. Public administration review, 70(5), 681-69o.

Peters, B.G. (2001). The Politics of Bureaucracy. Abingdon: Routledge.

Peters, G., \& Barker, A. (1993). Advising West European Governments: Inquiries, Expertise and Public Policy. Edinburgh: Edinburgh University Press. 
Randma-Liiv, T., \& Drechsler, W. (2017). Three decades, four phases: public administration development in central and Eastern Europe, 1989-2017. International Journal of Public Sector Management, 30(6-7), 595-605.

Raudla, R. (2012). Pitfalls of contracting for policy advice: preparing performance budgeting reform in Estonia. Governance, 26(4), 605-629.

Rose, R.A. (1988). Organizations as multiple cultures: a rules theory analysis. Human Relations, 41(2), 139-170.

Schäfer, H. (2004). Priests, prophets or sorcerers? on intellectual elites and politics in modernizing Latin America. In I. Lawford (Ed.), The Role of the Educated Class in Africa: Between African Renaissance and Globalisation Critique (pp. 193-219). Rehburg: Loccum.

Schmitt-Egner, P. (2015). Gemeinwohl: Konzeptionelle Grundlinien zur Legitimität und Zielsetzung von Politik im 21. Jahrhundert. Nomos.

Sedláček, V., \& Veselý, A. (2016). Policy Analysis Outsourcing. In A. Veselý, M. Nekola, \& E. Hejzlarová (Eds.), Policy Analysis in the Czech Republic (pp. 203-214). Bristol: Policy Press University of Bristol.

Staroňová, K. (2014). L'institutionnalisation des études d'impact en Europe centrale et orientale" (Institutionalization of the Regulatory Impact Assessment in (EE countries). Revue Francaise D'Administration Publique, 149(1), 123-143.

Staroňová, K., \& Gajduschek, G. (2017). Politicization beyond the meritsystem façade: the intricate relationship between formal and informal institutions in the senior civil service systems in Central and Eastern Europe. XXI IRSPM Annual Conference, 19-21 April 2017, Budapest, Hungary.

Staroňová, K., \& Rybář, M. (2018). Ministerial or party roots of civil service patronage? Evidence from a parliamentary democracy. $68^{\text {th }}$ Political Studies Association Annual International Conference, 26-28 March 2018, Cardiff, UK.
Sundell, A. (2014). Are formal civil service examinations the most meritocratic way to recruit civil servants? Not in all countries. Public Administration, 92(2), 440-457.

Van den Berg, C. (2017). Dynamics in the Dutch policy advisory system: externalization, politicization and the legacy of pillarization. Policy Sciences, 50(1), 63-84.

Van Maanen, J., \& Barley, S. (1985). Fragments of a theory. In P.J. Frost, L.F. Moore, M.R.E. Louis, C.C. Lundberg, \& J.E. Martin (Eds.), Organizational Culture (pp. 31-55). Beverly Hills, CA: Sage.

Vandenabeele, W., \& Van de Walle, S. (2008). International Differences in public service motivation: comparing regions across the world. In J.L. Perry, \& A. Hondeghem (Eds.), Motivation in Public Management: The Call of Public Service (pp. 223-244). Oxford: Oxford University Press.

Van de Haar, E. (2015). CPB Netherlands Bureau for Economic Policy Analysis: Dutch (economic) policy-making. Contemporary Social Science, 10(2), 182-190.

Veit, S., Hustedt, T., \& Bach, T. (2017). Dynamics of change in internal policy advisory systems: the hybridization of advisory capacities in Germany. Policy Sciences, 50(1), 50-63.

Veselý, A. (2013). Externalization of policy advice: theory, methodology and evidence. Policy and Society, 32(3), 199-209.

Wallace, W. (1996). Truth and power, monks and technocrats: theory and practice in international relations. Review of International Studies, 22(3), 301-321.

Wenger, E. (1998). Communities of Practice: Learning, Meaning and Identity. Cambridge: Cambridge University Press.

Yanow, D. (1996) How Does a Policy Mean? Interpreting Policy and Organizational Actions. Washington D.C.: Georgetown University Press. 